\title{
THE INTERFACE BETWEEN RELIGION AND POLITICS IN THE PHILIPPINES BASED ON DATA FROM RECENT PHILIPPINE ELECTIONS
}

\author{
Nestor T. Castro \\ University of the Philippines Diliman, Philippine \\ $<$ Ntcastro1@up.edu.ph>
}

\begin{abstract}
The Philippines held its national elections last May 2019. During the election campaign, several religious groups organized electoral slates or supported particular political candidates. Among these groups were the Iglesia ni Cristo (INC) with its Alagad Party, the Jesus is Lord (JIL) Movement with its CIBAC Party, the El Shaddai with its Buhay Party, and the Kingdom of Jesus Christ which supported all of the candidates backed by the Duterte government. On the other hand, the dominant Roman Catholic Church did not support any political party or candidate as a bloc but emphasized the need for the electorate to use their conscience and vote wisely. Some Roman Catholic priests, however, openly supported the opposition Otso Diretso slate for the Senate.

This paper looks at the interesting link between religion and politics in the Philippines, especially in its recent political history, i.e. from 1986 up to the present. In particular, this paper will attempt to answer the following questions: What role do the various religious groups in the Philippines play in the field of political arena? Do Filipinos vote based on their religious affiliation?
\end{abstract}

Key words: elections, politics, religion

\section{The Country Setting}

Southeast Asia is one of the most culturally diverse regions in the world. The region is diverse in terms of language, race and ethnicity, and religion. This characteristic is true for each country in the region, including the Philippines.

According to Ethnologue (2018), there are more than 170 languages in the Philippines with each language having several dialects. Most of 
these languages belong to the Western Malayo-Polynesian subfamily of the Austronesian family of languages.

Based on the 2000 Census of Population and Housing, eight of these languages are considered as the mother tongue of the majority ( $82 \%$ ) of Filipinos, namely Tagalog (28.16\%), Cebuano (23.12\%), Ilokano (9.07\%), Hiligaynon (7.57\%), Bikol (6.01\%), Waray (3.36\%), Kapampangan (3.03\%), and Pangasinan (1.78\%).

Language is also the primary criterion of identifying one's ethnic identity in the Philippines although other variables are also taken into consideration, such as the ethnic group's territory, phenotypic characteristics, various cultural traits, and religion.

Since ethnic differentiation is something that is cultural and not biological, there is no agreement as to how many ethnic groups there are in the Philippines. According to Jocano (1998), there are at least 106 ethnic groups in the Philippines. The eight biggest ethnolinguistic groups make up the dominant ethnic majority in the country while the rest constitute ethnic minorities.

There are various religious traditions in the Philippines as well although the majority of Filipinos belong to Christian denominations. According to the 2010 Census of Population and Housing, $81 \%$ of Filipinos are Roman Catholics while the rest are Muslims (5.1\%), Protestants (4.6\%), Iglesia ni Cristo (2.3\%), members of the Philippine Independent Church (2.0\%), and other religious sects $(5 \%)$.

Roman Catholicism was brought to the Philippines by the Spaniards when they ruled the country from 1565 until 1898. The Philippine Independent Church seceded from the Roman Catholic Church during the Philippine revolution against Spain in 1896. The said group is independent from the Vatican although its religious dogma follows the Roman Catholic beliefs and practices. Several Protestant denominations entered the Philippines during the period of American colonization, i.e. from 1898 until 1946. The Iglesia ni Cristo (literally meaning "Church of Christ") was founded in 1914 in the Philippines but now has several members in different parts of the world, especially among those of Filipino ancestry.

\section{Religion and Politics in Pre- colonial Philippines}

Prior to the coming of the Spanish in the Philippines, Filipinos were basically animists. According to Tylor (1873) animism refers to the belief in a dual existence in life - a physical body and a soul. Animists believe that humans have a body and soul but the same is true for animals, plants, and the natural features of the environment, such as the rivers and streams, the wind, rocks and mountains, etc. 
The Spanish chronicler Antonio de Morga (1609) documented that the natives of the Philippines believed in the presence of several spirits, including the ancestral spirits (called anito), environmental spirits called diwata (from the Sanskrit devata meaning deity or spirit), and several malevolent creatures found in nature.

In traditional Philippine society, there was no clear-cut dichotomy between the sacred and the profane. Religiosity, or more precisely spirituality, permeated all aspects of life, including political life. This can be gleaned from linguistic evidences. For example, the Tagalog term sala is used to refer to a crime against persons and properties as well as for a sin against gods or spirits (Castro 1990).

Moreover, the traditional village leaders, such as those of the headman or chieftain (usually called datu in many Philippine communities) exercised both political authority and ceremonial religious power.

\section{Religion and Politics in Colonial Philippine Society}

The Spanish colonizers ruled the Philippines for more than 300 years through the Cross and the sword. Those who were converted into the new Roman Catholic religion became part of the new colonial state. Those who resisted conversion were punished through military conquests.

During the three centuries of
Spanish rule, there was no separation between the Church and State. While there was a Spanish Governor-General who was in charge of the political administration of the Philippine colony, the Spanish friars often intervened in political matters.

This situation changed in 1898 when Filipinos were able to establish an independent political state, the Republic of the Philippines. The Philippine Constitution of 1898 highlighted the need for a separation between the Church and State. Although Filipino revolutionaries also established a Philippine Independent Church, the leaders of this Church did not intervene in the government's affairs.

Unfortunately, the independent Philippine Republic was short-lived as the Americans declared a war against Spain in 1898 and eventually acquired the Philippines from Spain. The Americans ruled the Philippines from 1898 until 1946, but briefly disrupted by the Japanese occupation from 1942 to 1945.

Fearful about the influence of the Philippine Independent Church, the American authorities allowed the Roman Catholic religious orders to regain ownership of their previous church lands and properties. In addition, the Americans administrators invited Protestant missionaries to come into the Philippines and establish religious missions in the new American colony. 


\section{Religion and Politics in Post- colonial Philippines}

The Philippines gained independence from United States in 1946. The Philippine Constitution of 1946 respected the separation between Church and State. However, this was mainly in paper but the reality on the ground was quite different. The Roman Catholic Church in the Philippines regained its strong influence in Philippine politics. Political candidates running for office generally courted the Roman Catholic Church hierarchy for support during election campaigns. However, the blessing and endorsement given by the Church did not always translate into election victories for these candidates.

In 1972, President Ferdinand Marcos declared martial law in the Philippines, abolished the Philippine Congress, and ruled exercised dictatorial powers over the country. At first, the Roman Catholic Church, led by Jaime Cardinal Sin, developed a strategy of critical collaboration with the Marcos regime. The Church hierarchy recognized Marcos' rule but criticized the policies of the regime especially in terms of its violation of human rights.

Because Marcos did not have the full support of the Roman Catholic Church, it courted the support of the Iglesia ni Cristo. During the snap elections of 1986, Cardinal Sin and the Roman Catholic Church supported opposition candidate Corazon Aquino while the Iglesia ni Cristo supported Marcos for President. Eventually Marcos was overthrown through a People Power Revolution in February 1986 and Corazon Aquino became the President of a restored Philippine democracy.

In 1987, the Philippines adopted a new Constitution. This Constitution reiterated the separation between religion and politics. According to Article II, Section 6 of the 1987 Constitution, "The separation between Church and State shall be inviolable." Moreover, Article III, Section 5 of the Constitution mentions

"No law shall be made respecting an establishment of religion, or prohibiting the exercise thereof. The free exercise and enjoyment of religious profession and worship, without discrimination or preference, shall forever be allowed. No religious test shall be required for the exercise of civil or political rights."

Again, these Constitutional provisions are good on paper but there were many cases of violation in reality. The Roman Catholic Church opposed government programs on family planning and reproductive health and continues to oppose proposals for legalizing divorce and re-imposing the death penalty. Of course, the Church would claim that they have the right to lobby on these matters since these issues fall within the realm of morality which, they believe, is within the mandate of any religious group. 
On the other, there have also been cases of the State's interference of internal Church matters, such as the 2011 scandal involving the Arroyo government's bribery of certain Catholic bishops in order to gain their political support for her administration's programs. It was revealed that several Catholic bishops received donations of SUV vehicles from the government in exchanged for political support.

\section{The 2016 and 2019 National Elec- tions}

During the 2016 Presidential Elections and the 2019 Midterm Elections, several religious groups participated in the electoral arena by filing candidacies in the party-list system. This system allowed for the representation of marginalized groups in the Lower House of the Philippine Congress.

Although originally intended for marginalized groups, the party-list system was taken advantage of by many political stakeholders, including politicians in power, by forming political parties that allegedly espouse certain civic causes. Religious groups organized their own political parties. Among these groups were the Iglesia ni Cristo (INC) with its Alagad Party, the Jesus is Lord (JIL) Movement with its CIBAC Party, the El Shaddai with its Buhay Party, and the Kingdom of Jesus Christ which supported all of the candidates backed by the Duterte government.

It is public knowledge in the Philippines that the Iglesia ni Cristo votes as a bloc. The members of the INC will vote for any political party or whoever political candidate that their Executive Minister Eduardo Manalo will ask them to vote for. This has been the practice of the INC even during the time of the leadership of its founder Eraño Manalo. Because of this practice, many politicians have courted the support of the INC leadership so that they are guaranteed with a large number of votes. In exchange, these political leaders give promises to appoint INC members in government positions if they win the elections. It must be said, however, that not all candidates supported by the INC won the elections. For example, the INC supported Ferdinand Marcos during the 1986 Presidential Elections and Eduardo Cojuangco during the 1992 Presidential elections but both candidates lost. On the other hand, Joseph Estrada won the elections in 1998, Gloria Macapagal Aquino won in 2004, Benigno Aquino won in 2010, and Rodrigo Duterte won in 2016, all of whom were supported by the Iglesia ni Cristo.

Surely, the INC is a religiouspolitical bloc to reckon with during Philippine elections. However, its actual strength has largely been exaggerated probably in order to court more political deals from incumbent and aspiring politicians. 
The Jesus is Lord Movement has also been active in electoral politics since 2004. JIL Founder and President Eduardo Villanueva ran as Presidential candidate during the 2004 and 2010 elections but lost on both occasions. However, his son Joel Villanueva ran for Congressman and then as Senator and won. Joel Villanueva also served as Director of the government's Technical Education and Skills Development Authority. The JIL-affiliated CIBAC party also won seats in the Philippine Congress.

The El Shaddai is a lay charismatic movement within the Roman Catholic Church. Its Spiritual Director is Brother Mike Velarde. During the May 2019 elections, Brother Mike openly endorsed the candidacy of 14 senatorial candidates, most of whom are aligned with President Duterte. The El Shaddai uses the Buhay Party as its political platform in joining the party-list elections. The Buhay Party garnered the most number of votes among all party lists during the 2007 and 2013 elections. However, it has been observed that the Buhay Party's strength has been dwindling. While it gained $7.3 \%$ of the total party-list votes in 2007 , the Buhay Party only got $4.6 \%$ of the party list votes in 2013 (COMELEC 2019). Moreover, even if the El Shaddai has been quite strong in the party-list elections, it had not been strong enough to make a difference in the Presidential and Senatorial elections.
A relatively new religious player in the political arena is the Kingdom of Jesus Christ, led by Pastor Apollo Quiboloy. Quiboloy is a close friend of President Duterte. President Duterte admitted that Quiboloy was one of his biggest financiers during the 2016 Presidential Elections. This religious sect also practices bloc voting similar to the Iglesia ni Cristo. During the 2019 Midterm Elections, Quiboloy endorsed all of the candidates backed by President Duterte and her daughter Sarah Duterte. However, the actual delivery of votes coming from the Kingdom of Jesus Christ is quite low because of the relatively fewer members of this group.

On the other hand, the dominant Roman Catholic Church (apart from the El Shaddai) did not support any political party or candidate as a bloc during the 2019 elections but emphasized the need for the electorate to use their conscience in voting wisely. Some Roman Catholic priests, however, openly supported the opposition Otso Diretso slate for the Senate. Unfortunately, all of the eight Otso Diretso candidates lost.

As for other religious groups in the country, there is no evidence that they have strong electoral influence. For example, Muslim groups in the Philippines do not single out Muslim candidates among those that they are supporting. Muslim Filipinos vote for candidates whether they are Muslims or not. 


\section{Postscipt}

There is currently an ongoing verbal war between President Duterte and the Roman Catholic Church. This is attributed to the critical stance of the Catholic Church against Duterte's so-called "War on Drugs." Because of this drug war, more than 7,000 people have been killed extra-judicially because of being mere suspects of engaging in the drug trade. The Roman Catholic Church has joined civil society organizations in criticizing this policy for being anti-poor and for violating human rights.

In retaliation, President Duterte has openly lambasted the Catholic Church during his public speeches. In June 23, 2018, Duterte criticized the Catholic God, mentioning "Who is this stupid God? This son of a bitch is then really stupid... How can you rationalize a God? Do you believe? What kind of religion is that? (Philippine Daily Inquirer)" Again on July 1, 2018, Duterte publicly announced, "Your
God is stupid, mine has common sense (Philippine Daily Inquirer)."

Last December 2018, Duterte challenged the people, "These bishops - kill them, these fools are good for nothing. All they do is criticize (Philippine Daily Inquirer)." Just last January 3, 2019, Duterte retorted, "Only I can say bishops are sons of bitches, damn you. That is true... Most of them are gay. They should come out in the open, cancel celibacy and allow them to have boyfriends (Philippine Daily Inquirer)."

These anti-Catholic statements have further set a political divide between many Roman Catholic leaders and members on one side and the Duterte administration on the other side. Many Catholic lay members are now challenging the Roman Catholic hierarchy in the Philippines to go back to its old role of being a counter-balance to authoritarianism, similar to the role of the Roman Catholic Church during the time of the Marcos dictatorship.[]

\section{References}

Castro, N. (1990). "Paglilitis, Pamamagitan, Paghatol: Indigenous Concepts of Land Dispute Processing in Silang, Cavite,” PSSC Social Science Information 18(3): 27-36.

Castro, N. (2005). "Kapangyarihan, Awtoridad at Moralidad sa Imnajbu," in Consuelo Joaquin-Paz, Gabay sa Fildwurk. Quezon City: University of the Philippines.

Commission on Elections (2019). Election Results. Accessed at www.comelec.gov.ph

Hollnsteiner, M.R. (1973). "Reciprocity in the Lowland Philippines," in Frank Lynch and Alfonso de Guzman, Four Readings on Philippine Values. Quezon City: Institute of Philippine Culture.

Morga, A. 1990 [orig. 1609] Sucesos de las Islas Filipinas. Manila: National Historical 
Institute.

National Statistical Coordination Board (2000). 2000 Census of Population and Housing. Makati: NSCB.

National Statistical Coordination Board (2010). 2010 Census of Population and Housing. Makati: NSCB.

Pertierra, R. (1988). Religion, Politics, and Rationality in a Philippine Community. Quezon City: Ateneo de Manila University Press.

Summer Institute of Linguistics (2018). Ethnologue. Accessed at www.ethnologue.com

Republic of the Philippines (1987). Constitution of the Republic of the Philippines. Quezon City: National Book Store.

Tylor, E. B. (1979) [orig. 1873]. “Animism," in W.A. Lessa (ed.), Reader in Comparative Religion: An Anthropological Approach, 9-19. New York: Harper Collins. 